\title{
The Influence of “Euro-Leaf” Logo on Consumers' Choices: The Italian Case of Branded and Private Label Food Products
}

\author{
Domenico Morrone $^{1} \&$ Rosamartina Schena ${ }^{1}$ \\ ${ }^{1}$ Lum Jean Monnet University, Italy \\ Correspondence: Domenico Morrone, Lum Jean Monnet University, Italy. E-mail: morrone@lum.it
}

Received: January 12, 2018

Accepted: February 20, 2018

Online Published: February 25, 2018

doi:10.5539/ijbm.v13n3p134

URL: https://doi.org/10.5539/ijbm.v13n3p134

\begin{abstract}
The eco-labels in food products is an increasing presence to underline a particular attention to sustainability issues by producers and, recently, also by retailers, through their private labels (PLs). In the last years there has been a proliferation of eco-labels, generating sometimes a real confusion in consumers' mind. Nevertheless, some of them could be really considered as a decisive factor to influence the purchasing process. It could be possible to affirm that they acquired a real "power", producing a tangible effect on consumers' behaviour. The present work is an attempt to calculate the effectiveness of one of the most well-known eco-label, "Euro-leaf", that indicates products coming from organic farming. The aim of the analysis is to evaluate its incidence in the choices related to food proposals. In particular, the latter have been considered in a double way, exploring the different categories among branded and PL offers, in the continuous challenge between these two branding policies in the retail sector. Therefore, to carry out the research, the methodology adopted has been the diffusion of a questionnaire to a wide sample. More of 1.000 Italian consumers have been reached using an on line platform, shaping a stratified sample. The data elaboration shows a final result where the euro-leaf logo is able to have the same positive influence on buying propensity related both to branded and PL products. Observing the dimension of this influence, valid information are provided for practitioners and researchers to highlight a market trend where all the potentials have not yet been expressed.
\end{abstract}

Keywords: brand, consumer behavior, eco-label, euro-leaf, food products, private label

\section{Introduction}

\subsection{The Eco-Label Framework}

The choice to adopt an eco-label, or an environmental label, is a way to reach basically two objectives (Galarraga Gallastegui, 2002). The first objective is to promote products with lower environmental impact, making consumers more informed about this effect in all stages of the life cycle (Erskine and Collins, 1997; Aguilar and Cai, 2010). The other one is to encourage producers, governments and other agents to increase the environmental standards of products/services (Galarraga Gallastegui, 2002). It is possible to observe many efforts to strength the role of eco-labels to promote more sustainable consumption patterns (Sitarz, 1994; Horne, 2009).

These efforts can come jointly from public organizations, as in the case of 1992 Rio Earth Summit (Agenda 21), or from private organizations. Ecolabelling, above all in the firm perspective, could be seen as a clear way to reinforce the corporate social responsibility (CSR) (Roheim, 2009), since it has been demonstrated a positive evolution of corporate environmental awareness due to the increasing phenomena of green consumers (D'Souza, 2004). On CSR direction (Lienbacher et al., 2013) companies need, to obtain first mover-advantages (Piacentini et al., 2000), to communicate their own CSR strategy to relevant stakeholders, including customers (Schmeltz, 2012). Eco-labels are realized to provide information to consumers about the environmental implications of purchasing the product (Tang et al., 2004). Moreover, the labelling schemes are strategic for the addition of moral dimensions to the normally amoral behaviour linking consumers and retail and production businesses (Hartlieb \& Jones, 2009).

Surely labelling alone is not the definitive solution to address sustainability issues in an effective way, but its relationship with other tools is a concrete step in this path (De Boer, 2003). It could be an important instrument to improve transparency and consumer's trust in environmental claims (Commission of the European 
Communities, 2007; Iraldo et al., 2005; Thøgersen, 2002). Until now, different investigations showed how green consumers are able to modify their consumption to protect the environment (Kassarjian, 1971; Brooker, 1976; Du Preez et al., 1994). Definitively, eco-labeling could be considered a market-based tool to transform homogenous products into differentiated ones, developing market shares of under-consumed eco-friendly products (Basu et al., 2003). Many researchers have even exposed that this environmental responsiveness could support organizations to be competitive and to increase market share too (Scerbinski, 1991; Ottman, 1993, Fitzgerald, 1993; Porter and Van der Linde, 1995). However, the growing interesting in eco-labelling produced a proliferation in the last years, above all in food sector (Antonicelli et al., 2015). This increasing number created confusion in consumers' minds, as expressed by Brécard (2014). He affirmed that eco-labelling is the best way to inform consumers on the environmental quality of goods but, at the same time, he observed also the effect of labels profusion, forcing the choice of consumer on the image of label, rather than intrinsic quality it guarantees. He underlined the willingness to pay more for an environmental product, but consumers are not able to identify it precisely from the current labels. From the technical point of view, eco-labels can be of three types (OECD, 1997). They represent a voluntary action, going from the adoption of a standard realized and verified in its application by a third party to the self-declaration of the producer related to a settled practice. In the first case, when there is the intervention of a third body, eco-label is often supported by governmental actions and there is a very good reputation and notoriety, since production protocols have a wide acceptance among economic agents in the market (Atănăsoaie, 2013). Belonging to the latter, there is the example of the "euro-leaf" (Fig. 1), a symbol indicating products coming from European organic agriculture. It is the result of the new Council Regulation made by European Agricultural Ministers (Note 1) to set out the principles, aims and overarching rules of organic production and to define how organic products were to be labelled (Note 2). In particular the "euro-leaf" figure was adopted as new logo for organic agriculture from 2010 (Note 3), substituting the previous one. The aim of this paper is to analyze the influence of "euro-leaf" logo as a key factor on consumers' choice between food products marked with a brand and food products marked with a PL in the retail dimension, where there is an increasing struggle between these categories.

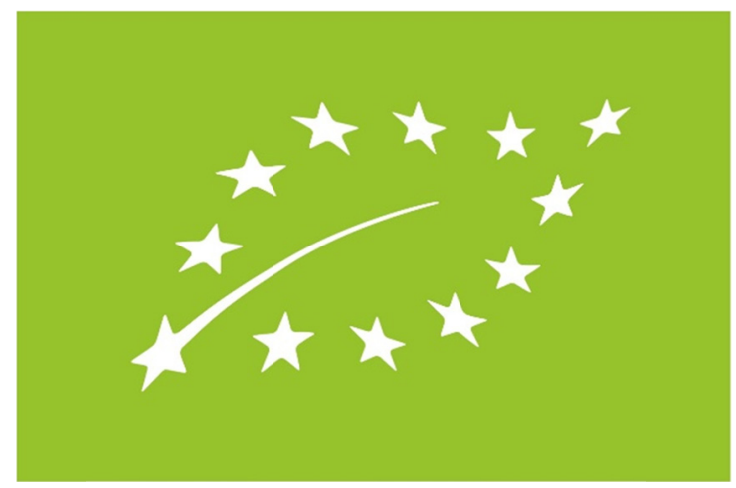

Figure 1. EU organic logo

\subsection{Organic Food Consumer and Organic Food Market in Italy}

The focus of this research is related to the influence of EU organic logo on consumer preferences. Before proceeding with the analysis, it is important to identify who are organic food consumers and the reasons of this way of consumption. The phenomena of organic food is not a remarkable trend developed only in Italy or in Europe. This value proposition is present almost in all markets worldwide but, specifically in Italy, organic foods selling expressed a particular improvement, as observed by Paul and Rana (2012). The definition of organic food consumer attracted the attention of many scholars and they produced in the last years different researches, bringing out the most relevant aspects. A work realized by Hughner et al. (2007), summarizing the previous findings provided by European and United States authors, explained very well the consumer attitudes toward organic food, identifying fifteen themes between the consumers' purchasing motives and the obstacles to purchase. Related to the first set, the reasons are: organic is healthier (Tregear et all., 1994: Huang, 1996; Hutchins and Greenhalgh, 1995; Schifferstein and Ophuis, 1998; Chinnici et al., 2002; Zanoli and Naspetti, 2002), it tastes better (Roddy et al., 1996; Schifferstein and Ophuis, 1998; Magnusson et al., 2001), it concerns environment (Roddy et al., 1996; Wandel and Bugge, 1997; Squires et al., 2001; Soler et al., 2002) as well as food safety (Jolly, 1991; Schifferstein and Ophuis, 1998; Soler et al., 2002) and animal welfare (Hill and Lynchehaun, 2002; Aarset et al., 2004), it supports local economy (Fotopoulos and Krystallis, 2002) and finally 
it is wholesome, it remembers the past and it is fashionable (Schifferstein and Ophuis, 1998; Chinnici et al., 2002; Hill and Lynchehaun, 2002). From the side of the obstacles there are: high prices (Byrne et al., 1992; Tregear et al., 1994; Roddy et al., 1996; Magnusson et al., 2001; Zanoli \& Naspetti, 2002), lack of availability (Zanoli and Naspetti, 2002), skepticism of certification boards (Ott, 1990; Canavari et al., 2002; Aarset et al., 2004), insufficient marketing (Roddy et al. 1996; Chryssochoidis, 2000), satisfaction with traditional foods (Roddy et al., 1994) and cosmetic defects (Ott, 1990; Thompson and Kidwell, 1998). In addition, the research made by Paul and Rana (2012) underlines as the preference for organic foods is affected by demographic features, availability and by the comparison with inorganic food. The presence of contrasting elements for a complete acceptance of organic foods is still supporting research on this issue, enlarging the perspectives on different features. Actually it is not possible to define precisely all the dimensions related to this offer. Scholars are still working to provide valid information on strategic aspects such as the market segmentation (Hansen et al., 2018; Peštek et al., 2018; Sultan et al., 2018), the role of awareness (Asif et al., 2018), the willingness to pay higher prices (Aschemann - Witzel, and Zielke, 2017), the country of origin (Thøgersen et al., 2017), the relationship with health concern (Apaolaza et al., 2018) or the perspectives on production (Popović et al., 2018). Analyzing the evidences from the market, increasing sales are registered. In Italy, where the research has been conducted, the last data available, taken from 2017 Nomisma (Note 4) Report about Italian organic trend, shows that in 2016 the value of organic food market was of almost EUR 5 billion, where EUR 3,0 billion was the value for domestic consumption and EUR 1,9 billion was the value for export. Domestic market grew of the 14\% towards the 2015 and of $121 \%$ towards 2008 , while export grew respectively of $16 \%$ and $408 \%$. Furthermore, the main retail channel is the large organized distribution, with a share of $37 \%(+20 \%$ towards 2015$)$, followed by specialized organic shops, and accounted to $30 \%(+3,5 \%$ on 2015). Considering the time period 2015-2016 exposed in the report, the number of organic food products marked with a PL grew of $26 \%$ (from 2.259 to 2.857 ). As it is possible to observe, this continue development is another interesting reason that supported the analysis carried out. Therefore, the first hypothesis of this research is:

Hypothesis 1 . The presence of euro-leaf label is an element of strong differentiation on foodstuffs independently from:

- $\quad$ H1a - the main foodstuffs attributes;

- $\quad$ H1b - the marketing levers adopted;

- $\quad \mathrm{H} 1 \mathrm{c}$ - the product category.

\subsection{Brand and Private Label in Food Retailing}

Private labels, also known as store brands, are brands owned by the distributor and sold in an exclusive store (Kotler and Armstrong, 1996). In the food industry, products marked with a brand owned or controlled by food retailer or wholesaler are not a novelty since, from the 1930', their proposal is a concrete offer, above all in US context (Call, 1967), with increasing market shares registered until now (Mathews, 1996). At the beginning these products were standard and related to few categories, even if actually they are producing a considerable pressure (Ward et al., 2002). This increasing presence has deeply modified the landscape of retail competition (Ezrachi \& Bernitz, 2009). As noted by Ward et al. (2002), there are different points of view that could be observed, and previous researches investigated why companies produce PL goods (Bontems et al., 1999; Galizzi et al., 1997) and why retailers offer them (Mills, 1995; Dhar \& Hoch, 1997; Narasimhan \& Wilcox, 1998), as well as the first differentiation between PL and branded products is focused above all on the price level (Conner \& Peterson, 1992; Hinloopen \& Martin, 1997; Putsis, 1997).In particular, the attitude towards PL products is reinforced by price/value consciousness and smart-shopper self-perceptions, as observed by Burton et al. (1998). Anyway, citing the work of Gyongyi et al. (2012), the PL strategies adopted by retailers moved, with the passage of time, to other dimensions, tracing different stages. In the first step, this offer was of low quality, with a price of $30 \%-50 \%$ lower than the price of branded products. The evolution turned to high standard and innovative 'individual' category, realizing the third and the fourth step. In this way PL products are now able to be a concrete option for every kind of customer demand and segment, being a real tool for the retail trade to reduce the requests of suppliers with well-known brands. Following this path, PL products are involved in different plans to improve their acceptance, reducing the gap with traditional brands. For example, to give a concrete idea of what above mentioned, it is useful to underline some evidences coming out from Wu et al. (2011). They suggest, evaluating the attribution theory (Sawyer and Dickson, 1984), that the joint presence of low prices and unprofessional campaigns, increased the quality gap between PL and national brand. Nevertheless, they detected as the store image and the service quality have a positive effect on PL purchase intention and image, reducing the above mentioned distance, where the interesting for PL could overcome price sensitive segments. According to 
Castaldo (2009), the actual development of PL products can be referred to the increased quality, packaging and assortment, made through retailers' important investments and fine tuned strategies. In addition, he affirms that this positive trend is depending also from a greater exposition to more products on store shelves, inviting customers to test and to repurchase them. Definitely this strong competition will continue to generate deeper researches to analyze the different responses of consumers, since actually there is an interesting level of differentiation. The latter, as above mentioned, is based on different aspects such as the price competition (Gielens, 2018; Olbrich et al., 2017), the quality of products (Nenycz-Thiel \& Romaniuk, 2016), the role of information (Rossi et al., 2015), the brand engagement or image (Gendel-Guterman et al., 2017, Liu et al.I, 2018), the brand equity (Girard et al., 2017) or the shopping experience (Kelting et al., 2017). In particular, the new market of organic food is also attracting the attention of the scholars in defining the competitive relation between organic manufacturers and retailers (Jonas \& Roosen, 2005; Reinders \& Bartels, 2017). The last data available on Italian context, provided by Censis (Note 5) (2017), confirmed the increasing importance of the large organized distribution, where the $90,4 \%$ of Italians went at least once a week. The large organized distribution channel sold in 2016 foodstuffs to more than $80 \%$ of Italians for a value of 115,5 billion Euros. In this channel the total PLs proposition registered in the 2017 an increasing selling $(+2.7 \%$ and $+1.7 \%$ versus 2016 respectively in value and volumes) with a market share of $18,5 \%$, well supported by organic $(+10,5 \%$ versus 2016) (Note 6). Therefore, evaluating the positive trend of PL products in their value proposition, it is possible to introduce the second hypothesis of this study, declaring that:

Hypothesis 2. The presence of euro-leaf is an element that improve the purchase propensity on foodstuffs, reducing in a relevant way the difference between branded and PL products.

\section{Method}

In order to investigate the relation between organic food stuffs belonging to a brand or to a PL, two main methods during the research were used, after highlighting the literature review and the last market trend:

- In-depth survey among consumers to collect data; and

- Statistical tools and techniques used to obtain final evidences.

A detailed description related to the questionnaire and the sample is described below.

\subsection{Questionnaire Development and Instrument}

The data has been collected through a structured questionnaire which was designed parallel with the objectives of this study. Questions were composed following the most important suggestions coming from the methodological approach in marketing research (Churchill \& Iacobucci, 2006; Brace, 2008; Fowler, 2013). The relevance and measurement scales of the questions were given due weightage. To reach a significant sample in a short time, without geographical limits, an on line platform has been utilized. In particular, this investigation covered all Italian territory. It lasted for all 2017, considering every kind of consumer, without any particular distinction in terms of gender, education or other features. The reason of this wide vision in sample building was that the survey had to include all possible customers of the mass distribution circuit. The only exclusion was for those under 18 years of age, due to the limited spending capacity and to the impossibility of buying, by law, alcoholic beverages (one of the categories listed). The counted questionnaires were only those with complete answers and the use of web accelerated all process. The survey included four sections: demography, information, remark (emotional) and behavior. Demography section explored few but essential demographic items such as gender, age, income, education, qualification and job. Information section investigated the level of information about: the features of food products that consumer intend to buy, the euro-leaf logo and the products derived from organic farming. The information level has been evaluated with a five-point Likert's scale (where ' 1 ' and '5' signified a least and most informed respectively) asking the favorite source of information for food buying (label, web, TV, etc.). In the remark (emotional) section the focus was on marketing mix instruments (advertising, price, packaging, etc.) and products features (quality, safety, environmental respect, etc.). To have a precise panorama in this last investigation, using always a five-point Likert's scale (where ' 1 ' and ' 5 ' mean respectively a minimum and a greater importance), every respondent had to consider four different cases: 1. the product is branded; 2: the product is marked with a private-label; 3: the product is branded, and it has the euro-leaf logo too; 4: the product is marked both with a private label and the euro-leaf logo. Lastly, behavior section included questions about consumer purchasing preferences regarding 10 foodstuffs, building a precise framework considering the main food and beverages categories: fruits and vegetables, salami, cheese, alcoholic drinks, alcohol-free drinks, cakes and cookies, meat, pasta, sauces and ingredients (sugar, oil, yeast, etc.). For each product category respondents had to express their purchasing preference through five-point Likert's scale (where '1' and '5' signified a least and most importance respectively). Also for this fourth section, the case exposed to respondents were the same of the 
third section. Moreover, this section included questions about the frequency of organic products purchasing. A last question was settled in the questionnaire as a question-control, asking respondents to spur their purchasing preference when they could choose the same organic product with the only one difference in branding (brand or PL).

\subsection{Data and Sample}

The on-line survey reached 1.546 persons but, evaluating only the complete answers, 1.201 completed questionnaires were collected for the investigation. Participants, including Italian citizens without a geographical limitation, were $53 \%$ male and $47 \%$ female. The average age was 37 . The average size of participants' households was two or three persons, while the average monthly income was below Euro 2.999,00. Therefore, it could be considered a well stratified sample. In the Table 1 there are all description evidences of this sample.

Table 1. Sample composition (in percentage, \%)

\begin{tabular}{|c|c|c|c|c|c|}
\hline Gender & Age (years) & Education & $\begin{array}{c}\text { Family } \\
\text { members }\end{array}$ & Profession & Monthly income $(€)$ \\
\hline Male, 53 & $18-24,23$ & High school or below, 46 & $<2,43$ & Student, 25 & $<999,6$ \\
\hline \multirow[t]{5}{*}{ Female, 47} & $25-30,23$ & College or university, 49 & $3-4,54$ & Looking for a job, 12 & $1.000-1.999,31$ \\
\hline & $31-45,26$ & Postgraduate, 5 & $5-6,3$ & Entrepreneur, 4 & $2.000-2.999,31$ \\
\hline & $46-60,22$ & & & Freelance, 20 & $>3.000,32$ \\
\hline & $>60, \quad 6$ & & & Worker, 36 & \\
\hline & & & & Retired, 3 & \\
\hline
\end{tabular}

Regarding to the level of information about the foodstuffs to be purchased, the sample is 'average' informed value 4 of the Likert scale - while the level of information on products derived from organic farming is 'slightly lower' - value 3 of the Likert scale. Furthermore, $77 \%$ of respondents stated that they know the euro-leaf symbol. The means used to be informed, where it was possible to indicate one or more options, are mostly label and web, as represented in the Figure 2.

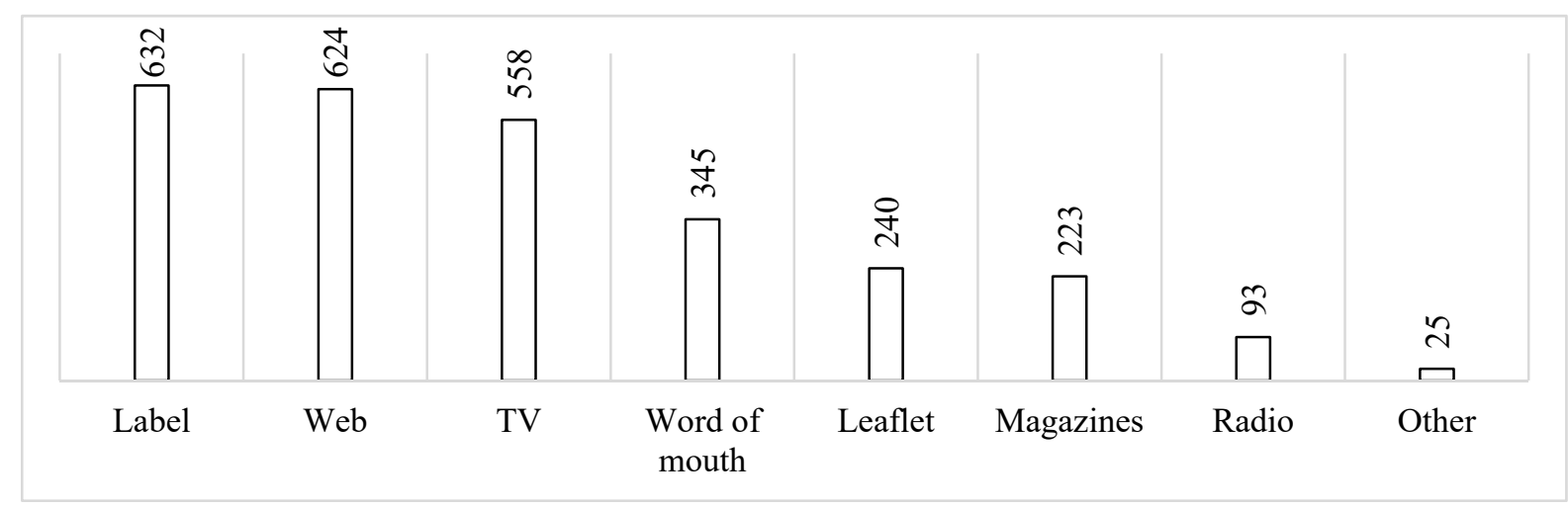

Figure 2. Favorite information source about foodstuffs (absolute values)

\section{Results}

To analyze the information obtained through questionnaires, different statistical tools and techniques were adopted. At the questionnaire design stage, it was decided to use various multivariate analyses like factor analysis.

\subsection{Euro-leaf label Is an Element of Strong Differentiation on Foodstuffs (H1)}

To test the first hypothesis three factor analysis were run, to verify the influence of euro-leaf logo on food products, independently from the association with a brand or a PL. The three factor analysis are related to remark (H1a and $\mathrm{H} 1 \mathrm{~b})$ and category (H1c) sections.

\subsubsection{Remark Factor Analysis (H1a and H1b)}

In remark section the analysis is referred to two questions' types: product and marketing factor, to test the H1a and H1b hypothesis. The first questions' type included items such as quality, healthiness, safety, ingredients, 
taste, and environmental respect; instead marketing questions included items such as advertising, price, promotion and packaging. The first evaluation was related to product variables through Exploratory Factor Analysis (EFA), using Principal Component Analysis (PCA) with Varimax Rotation. The sample adequacy value under Kaiser-Meyer-Olkin (KMO) was .938 and Bartlett's Test of Sphericity was significant. For the above mentioned factor analysis, the communality values were in the acceptable range for all the attributes. Four factors had eigenvalues over Kaiser's criterion of 1 and, in combination, explained $70.03 \%$ of variance. The scree plot was very ambiguous and showed inflexions that could justify retaining either three or four factors. Three factors were retained due to: the large sample size, the convergence of the scree plot and Kaiser's criterion on the latter. Three factors in combination explained $65.80 \%$ of variance. Then, the variables were evaluated through Confirmatory Factor Analysis (CFA) with three factors.

\section{Factor loadings and interpretation of product factors}

A reliability analysis was made on variables that include factors. Cronbach's Alpha showed that questionnaire achieved acceptable reliability. All the items were worthy of conservation, resulting in lower alpha if eliminated. Below the results obtained (Table 2).

- $\quad 1^{\text {st }}$ Factor: the first factor included product variables in the assumption that the product had the euro-leaf logo associated both with PL and brand. For this reason, this factor is labelled as "Euro-leaf product".

- $\quad 2^{\text {nd }}$ Factor: the second factor was labelled as "PL product" since this factor included elements with the presence of PL in the questions.

- $\quad 3^{\text {rd }}$ Factor: the third factor, named "Brand product", included manufacturing items in the case of the brand.

Table 2. Rotated component matrix (a)

\begin{tabular}{|c|c|c|c|}
\hline & \multicolumn{3}{|c|}{ Component } \\
\hline & 1 & 2 & 3 \\
\hline BrandEuroleaf[quality] &, 833 & & \\
\hline BrandEuroleaf[ingredients] &, 814 & & \\
\hline BrandEuroleaf[environmental respect] &, 807 & & \\
\hline BrandEuroleaf[safety] & ,799 & & \\
\hline BrandEuroleaf[healthiness] & ,774 & & \\
\hline PLEuroleaf[environmental respect] & ,738 & & \\
\hline BrandEuroleaf[taste] &, 731 & & \\
\hline PLEuroleaf[quality] &, 729 & & \\
\hline PLEuroleaf[healthiness] &, 724 & & \\
\hline PLEuroleaf[ingredients] &, 720 & & \\
\hline PLEuroleaf[safety] &, 716 & & \\
\hline PLEuroleaf[taste] & ,686 & & \\
\hline PL[healthiness] & &, 765 & \\
\hline PL[ingredients] & &, 758 & \\
\hline PL[quality] & &, 752 & \\
\hline PL[taste $]$ & &, 748 & \\
\hline PL[environmental respect] & &, 746 & \\
\hline PL[safety] & &, 731 & \\
\hline Brand[quality] & & & ,773 \\
\hline Brand[healthiness] & & &, 757 \\
\hline Brand[safety] & & &, 725 \\
\hline Brand[ingredients] & & &, 719 \\
\hline Brand[taste] & & & 698 \\
\hline Brand [environmental respect] & & & 684 \\
\hline Cronbach Alpha $(\alpha)$ & ,950 &, 903 & 871 \\
\hline
\end{tabular}

Notes - Extraction method: principal component analysis; rotation method: varimax with Kaiser normalization; rotation converged in six iterations.

With the results above exposed, the H1a hypothesis is verified, since all products marked with euro-leaf are grouped in only one component, deleting the identification with a brand or a PL.

Progressing with the analysis, there were the marketing variables (in the marketing mix the "place" lever was the 
only one to be excluded, since the research was considered in the mass distribution circuit only) evaluation through EFA using PCA with Varimax Rotation. The sample adequacy value under KMO is .810 and Bartlett's Test of Sphericity is significant. The communality values were in the acceptable range for all the attributes. Five factor had eigenvalues over Kaiser's criterion of 1 and in combination explained $69.34 \%$ of variance. Also in this case, the scree plot was very ambiguous and showed inflexions that could justify retaining either three or four factors. Three factors were retained for the usual motivations. Three factors in combination explained $54.70 \%$ of variance.

\section{Factor loadings and interpretation of marketing factors}

Also in this case a reliability analysis was made on variables that include factors. Cronbach's Alpha showed that the questionnaire achieved acceptable reliability.

Below the result obtained (Table 3).

$1^{\text {st }}$ Factor: the first factor included marketing variables in the assumption that the products had the euro-leaf both with brand and PL. This factor is labelled as "Euro-leaf strategy".

$2^{\text {nd }}$ Factor: the second factor included marketing questions with the presence of PL. Therefore, it is labelled as "PL strategy".

$3^{\text {rd }}$ Factor: the third factor, named "Brand strategy", included marketing items in the case of the brand.

Table 3. Rotated component matrix (a)

\begin{tabular}{|c|c|c|c|}
\hline & \multicolumn{3}{|c|}{ Component } \\
\hline & 1 & 2 & 3 \\
\hline BrandEuroleaf[advertising] &, 744 & & \\
\hline PLEuroleaf[packaging] &, 710 & & \\
\hline BrandEuroleaf[packaging] &, 706 & & \\
\hline BrandEuroleaf[promotion] & ,689 & & \\
\hline PLEuroleaf[promotion] & ,682 & & \\
\hline PLEuroleaf[advertising] & ,675 & & \\
\hline PLEuroleaf[price] &, 583 & & \\
\hline BrandEuroleaf[price] &, 559 & & \\
\hline PL[advertising] & & ,802 & \\
\hline PL[price] & & 677 & \\
\hline PL[promotion] & & ,627 & \\
\hline PL[packaging] & & 420 & \\
\hline Brand[advertising] & & &, 755 \\
\hline Brand[packaging] & & & ,729 \\
\hline Brand[price] & & & ,701 \\
\hline Brand[promotion] & & & ,490 \\
\hline Cronbach Alpha $(\alpha)$ & ,863 & ,714 & ,713 \\
\hline
\end{tabular}

Notes - Extraction method: principal component analysis; rotation method: varimax with Kaiser normalization; rotation converged in six iterations.

Following these last results, the H1b hypothesis is verified. Euro-leaf is able to group all marketing levers adopted for food products, independently if they are marked with a brand or a PL.

\subsubsection{Category Factor Analysis (H1c)}

In the first step of the measurement technique, the variables were evaluated through EFA using PCA with Varimax Rotation. The sample adequacy value under KMO is .932, which is higher than .5 and Bartlett's Test of Sphericity is significant. In this case the communality values were in the acceptable range too. An initial analysis was run to obtain eigenvalues for each factor in the data. Six-factors had eigenvalues over Kaiser's criterion of 1 and, in combination, they explained $70.70 \%$ of variance. The scree plot was ambiguous and showed inflexions that could justify retaining four factors. Four factors were retained due to: the large sample size, the convergence of the scree plot and Kaiser's criterion on the latter. Four factors have been considered to be acceptable from the ploot's point of inflexion study, accounting for $63.66 \%$ of variance explained.

Factor loadings and interpretation of category factors 
The Cronbach's Alpha showed that the questionnaire achieved acceptable reliability. The results obtained can be described as follows (Table 4):

$1^{\text {st }}$ Factor: this factor consisted of foodstuffs with euro-leaf, marked both with brand and PL, with the exception of beverages. Thus, this factor is labeled as "Euro-leaf influence in food".

$2^{\text {nd }}$ Factor: this factor consisted of all products marked only with a PL. Thus, this factor is labeled as " $P L$ influence".

$3^{\text {rd }}$ Factor: the third factor grouped foodstuffs with a brand, so it is labeled as "Brand influence".

$4^{\text {th }}$ Factor: the fourth factor included the alcoholic and alcohol free beverages with euro-leaf, marked both with a brand and with a PL. This factor is labeled as "Euro-leaf influence in beverage".

Table 4. Rotated component matrix (a)

\begin{tabular}{|c|c|c|c|c|}
\hline & \multicolumn{4}{|c|}{ Component } \\
\hline & 1 & 2 & 3 & 4 \\
\hline PLEuroleaf[cheese] &, 831 & & & \\
\hline PLEuroleaf[meat] &, 828 & & & \\
\hline PLEuroleaf[pasta] &, 823 & & & \\
\hline PLEuroleaf[salami] &, 809 & & & \\
\hline PLEuroleafffruits and vegetables] &, 799 & & & \\
\hline BrandEuroleaf[meat $]$ &, 786 & & & \\
\hline BrandEuroleaf[cheese] &, 779 & & & \\
\hline PLEuroleaf[sauces] &, 778 & & & \\
\hline BrandEuroleaf[pasta] &, 778 & & & \\
\hline PLEuroleaf[ingredients] &, 771 & & & \\
\hline PLEuroleaf[sweets and derivatives] &, 767 & & & \\
\hline BrandEuroleaf[salami] &, 762 & & & \\
\hline BrandEuroleaf[sauces] &, 756 & & & \\
\hline BrandEuroleaf[ingredients] &, 744 & & & \\
\hline BrandEuroleaf[fruits and vegetables] &, 741 & & & \\
\hline BrandEuroleaf[sweets and derivatives] &, 709 & & & \\
\hline $\mathrm{PL}$ [cheese] & &, 840 & & \\
\hline PL[sauces] & &, 835 & & \\
\hline $\mathrm{PL}[$ pasta] & & 835 & & \\
\hline PL[salami] & &, 829 & & \\
\hline PL[meat $]$ & &, 807 & & \\
\hline PL[sweets and derivatives] & & ,796 & & \\
\hline PL[ingredients] & & ,789 & & \\
\hline PL[alcohol free beverages] & & ,784 & & \\
\hline PL[alcoholic beverages] & & ,735 & & \\
\hline PL[fruits and vegetables] & &, 721 & & \\
\hline Brand[sauces] & & & ,730 & \\
\hline Brand[pasta] & & & 723 & \\
\hline Brand[sweets and derivatives] & & & ,721 & \\
\hline Brand[salami] & & & ,713 & \\
\hline Brand[cheese] & & & ,708 & \\
\hline Brand[alcohol free beverages] & & & 666 & \\
\hline Brand[meat] & & & ,636 & \\
\hline Brand[ingredients] & & &, 621 & \\
\hline Brand[alcoholic beverages] & & &, 575 & \\
\hline Brand[fruits and vegetables] & & &, 519 & \\
\hline BrandEuroleaf[alcoholic beverages] & & & & ,734 \\
\hline PLEuroleaf[alcoholic beverages] & & & &, 730 \\
\hline BrandEuroleaf[alcohol free beverages] & & & &, 711 \\
\hline PLEuroleaf[alcohol free beverages] & & & & 686 \\
\hline Cronbach Alpha $(\alpha)$ & 964 & ,945 & .876 & 911 \\
\hline
\end{tabular}

Notes - Extraction method: principal component analysis; rotation method: varimax with Kaiser normalization; rotation converged in six iterations 


\subsection{The Presence of Euro-Leaf Is an Element That Improve the Purchase Propensity on Foodstuffs, Reducing in} A Relevant Way the Difference between Branded and PL Products. (H2)

The test of the second hypothesis is the summary of the results obtained from the three factor analysis previously elaborated (Table 2, Table 3 and Table 4). In all cases, considering the main foodstuffs attributes, the marketing levers adopted and the categories, the euro-leaf presence has combined all offers, coming indistinctly from a PL or a brand, in only one component. Conversely, when the different items are analyzed without the euro-leaf, there is a clear distinction between brand and PL components. In particular, euro-leaf is able to group PL and brand value propositions in the first component of all factor analysis, except the case of the categories, where this influence is able to define one component related to beverage only (Table 4). Moreover, the H2 hypothesis can be tested in a direct way observing and comparing also four questions of the questionnaire, exposed in the Table 5. These four questions investigated, for each product category (fruits and vegetables, pasta, cheese, etc.) respectively the importance of the brand, the importance of the PL and the increasing buying propensity with the addition of euro-leaf logo. The respondents had to give, for each question/category, an answer with values among 1 and 5, following the Likert scale, where 1 indicated "not at all" and 5 indicated "very much". It is remarkable as the presence of euro-leaf on packaging is able to increase, approximately at the same level, the purchase propensity towards product marked both with a PL and with a brand. Above all on beverage the increasing buying propensity is the same and the initial difference between the two typologies of branding is totally irrelevant. This last result is in line with the third factor analysis (Table 4).

Table 5. Brand/PL importance and the effect of euro-leaf presence

\begin{tabular}{|c|c|c|c|c|c|c|}
\hline & $\begin{array}{l}\text { In your food } \\
\text { buying } \\
\text { preferences, } \\
\text { how important } \\
\text { is the brand?* }\end{array}$ & $\begin{array}{l}\text { In your food } \\
\text { buying } \\
\text { preferences, } \\
\text { how important } \\
\text { is the PL?* }\end{array}$ & $\begin{array}{l}\text { How much } \\
\text { would increase } \\
\text { your buying } \\
\text { propensity } \\
\text { towards brand } \\
\text { food product, if } \\
\text { there is the } \\
\text { euro-leaf } \\
\text { logo?* }\end{array}$ & $\begin{array}{l}\text { How much } \\
\text { would increase } \\
\text { your buying } \\
\text { propensity } \\
\text { towards PL } \\
\text { food product, if } \\
\text { there is the } \\
\text { euro-leaf } \\
\text { logo?* }\end{array}$ & $\begin{array}{l}\text { Difference } \\
\text { between brand } \\
\text { and PL } \\
\text { importance }\end{array}$ & $\begin{array}{l}\text { Difference of } \\
\text { increasing } \\
\text { buying } \\
\text { propensity } \\
\text { between brand } \\
\text { and PL product } \\
\text { with euro-leaf } \\
\text { logo }\end{array}$ \\
\hline Fruits and vegetables & 3,4 & 2,7 & 3,5 & 3,4 & 0,8 & 0,1 \\
\hline Salami & 3,5 & 2,9 & 3,4 & 3,3 & 0,7 & 0,1 \\
\hline Cheese & 3,4 & 2,9 & 3,6 & 3,4 & 0,5 & 0,2 \\
\hline Alcoholic beverages & 3,4 & 2,6 & 2,7 & 2,7 & 0,7 & 0,0 \\
\hline Alcohol free beverages & 3,4 & 2,8 & 2,9 & 2,9 & 0,7 & 0,0 \\
\hline Sweets and derivatives & 3,6 & 3,0 & 3,4 & 3,4 & 0,6 & 0,1 \\
\hline Meat & 3,6 & 3,0 & 3,7 & 3,5 & 0,6 & 0,2 \\
\hline Pasta & 3,7 & 3,0 & 3,6 & 3,5 & 0,7 & 0,2 \\
\hline Sauces & 3,6 & 2,9 & 3,5 & 3,3 & 0,7 & 0,1 \\
\hline Ingredients & 3,4 & 3,0 & 3,5 & 3,4 & 0,4 & 0,1 \\
\hline Final value** & 3,5 & 2,9 & 3,4 & 3,3 & 0,6 & 0,1 \\
\hline
\end{tabular}

Notes. *the value in the columns are the average values calculated from all 1.201 answers obtained; $* *$ for the first four columns the final value is the mean of the results above exposed.

\section{Discussion}

The results above exposed are a valid contribution into two different fields. The first and more important context analysed is surely the eco-labels framework. Eco-labels are voluntary tools adopted to demonstrate concretely a renewed attention to environmental issues. However, they acquired a wider meaning in the last decades, incorporating social and economic instances too. Moreover, the acceptance from customer perspective grew in a relevant way, even if, in some cases, an insufficient information level produced negative results (Delmas et al., 2013). The study provides empirical evidence of the value generated by euro-leaf logo.

The factor analysis' results showed that the euro-leaf is a distinctive sign, capable of guaranteeing quality, health, safety of product and respect for the environment.

In addition, although the proliferation of eco-labels, the value proposition of euro-leaf is clear and consistent, and 
it is able to be translated into a competitive strategy, confirming the influence of sustainable perspective on marketing outcomes (Morrone, 2012). The advantage of the euro-leaf adoption is also a new element that could be observed in the traditional competition between foodstuffs branded or marked with PL. There is a wide literature that dealt about this contraposition observing issues as the brand equity and other related aspects and the introduction of this "third" label is an element that will reserve an important evolution for the future. In fact, considering the results obtained, this logo is able to produce a concrete influence independently from the brand origin of the product. Surely, further investigation could deeply focus other aspects coming from, for example, a cluster analysis for the comprehension of the different behaviors related to some variables as age, income, education, etc.

Data collection and analysis were limited to the Italian consumers, so future research could include data from different countries and regions. The data were collected at one point over time, hence essentially from a fixed point of view. Next steps should focus on conducting longitudinal studies of purchasing patterns, taking into account subtleties in consumers' behaviours and attitudes. Finally, the results above described leave a wide margin of inquiry towards other relevant academic and managerial issues.

\section{References}

Aarset, B., Beckmann, S., Bigne, E., Beveridge, M., Bjorndal, T., Bunting, J., McDonagh, P., Mariojouls, C., Muir, J., Prothero, A., Reisch, L., Smith, A., Tveteras, R., Young, J. (2004). The European consumers' understanding and perceptions of the "organic" food regime: The case of aquaculture. British food journal, 106(2), 93-105. https://doi.org/10.1108/00070700410516784

Aguilar, F. X., \& Cai, Z. (2010). Conjoint effect of environmental labeling, disclosure of forest of origin and price on consumer preferences for wood products in the US and UK. Ecological Economics, 70(2), 308-316. https://doi.org/10.1016/j.ecolecon.2010.09.002

Antonicelli, M., Calace, D., Morrone, D., Russo, A., \& Vastola, V. (2015). Information or confusion? The role of ecolabels in agrifood sector. Analele Universităţii din Oradea, Fascicula Ecotoxicologie, Zootehnie şi Tehnologii de Industrie Alimntară, Vol. XIV/A, 187-195.

Aschemann-Witzel, J., \& Zielke, S. (2017). Can't buy me green? A review of consumer perceptions of and behavior toward the price of organic food. Journal of Consumer Affairs, 51(1), 211-251. https://doi.org/10.1111/joca.12092

Asif, M., Xuhui, W., Nasiri, A., \& Ayyub, S. (2018). Determinant factors influencing organic food purchase intention and the moderating role of awareness: A comparative analysis. Food Quality and Preference, 63, 144-150. https://doi.org/10.1016/j.foodqual.2017.08.006

Atănăsoaie, G. S. (2013). Eco-Label and its Role in the Development of Organic Products Market. Economy Transdisciplinarity Cognition, 16(1).

Apaolaza, V., Hartmann, P., D'Souza, C., \& López, C. M. (2018). Eat organic-Feel good? The relationship between organic food consumption, health concern and subjective wellbeing. Food Quality and Preference, 63, 51-62. https://doi.org/10.1016/j.foodqual.2017.07.011

Basu, A. K., Chau, N. H., \& Grote, U. (2003). Eco-Labeling and Stages of Development. Review of Development Economics, 7(2), 228-247. https://doi.org/10.1111/1467-9361.00188

Bhattacharyya, S. S. (2010). Development of a scale on strategic corporate social responsibility constructs. International Journal of Indian Culture and Business Management, 3(2), 181-207. https://doi.org/10.1504/IJICBM.2010.030753

Bontems, P., Monier-Dilhan, S., \& Réquillart, V. (1999). Strategic effects of private labels. European Review of Agricultural Economics, 26(2), 147-165. https://doi.org/10.1093/erae/26.2.147

Brace, I. (2008). Questionnaire design: How to plan, structure and write survey material for effective market research. Kogan Page Publishers.

Brécard, D. (2014). Consumer confusion over the profusion of eco-labels: Lessons from a double differentiation model. Resource and energy economics, 37, 64-84. https://doi.org/10.1016/j.reseneeco.2013.10.002

Brooker, G. (1976). The self-actualizing socially conscious consumer. Journal of Consumer Research, 3(2), 107-112. https://doi.org/10.1086/208658

Burton, S., Lichtenstein, D. R., Netemeyer, R. G., \& Garretson, J. A. (1998). A scale for measuring attitude toward private label products and an examination of its psychological and behavioral correlates. Journal of 
the Academy of Marketing Science, 26(4), 293-306. https://doi.org/10.1177/0092070398264003

Byrne, P., J., Toensmeyer, U., C., German, C., L., \& Muller H., R. (1992). Evaluation of consumer attitudes towards organic produce in Delaware and the Delmarva region. Journal of Food Distribution Research, 23(1), 29-44.

Call, D. L. (1967). Private label and consumer choice in the food industry. Journal of Consumer Affairs, 1(2), 149-160. https://doi.org/10.1111/j.1745-6606.1967.tb00802.x

Canavari, M., Bazzani, G., M, Spadoni, R., \& Regazzi, D. (2002). Food safety and organic fruit demand in Italy: a survey. British Food Journal, 104(3/4/5): 220-232. https://doi.org/10.1108/00070700210425688

Castaldo, S. (2009). Private Labels: Purchase Precedes Trust in Retailer. IESE Insight, 3, 28-35

Censis (2017). Lo sviluppo italiano e il ruolo sociale della distribuzione moderna organizzata. ADM Associazione Distribuzione Moderna with Federdistribuzione - ANCC COOP - ANCD CONAD

Chinnici, G., D'Amico, M., \& Pecorino, B. (2002). A multivariate statistical analysis on the consumers of organic products. British Food Journal, 104(3/4/5), 187-199. https://doi.org/10.1108/00070700210425651

Chryssochoidis, G. (2000). Repercussions of consumer confusion for late introduced differentiated products. European Journal of Marketing, 34(5/6), 705-722. https://doi.org/10.1108/03090560010321992

Churchill, G. A., \& Iacobucci, D. (2006). Marketing research: methodological foundations. New York: Dryden Press.

Commission of the European Communities (2007). Accompanying Document to the Communication from the Commission to the Council and the European Parliament: Progress Report on the European Union Sustainable Development Strategy 2007, Commission of the European Communities, Brussels, 22 October.

Connor, J. M., \& Peterson, E. B. (1992). Market-structure determinants of national brand-private label price differences of manufactured food products. The Journal of Industrial Economics, 157-171. https://doi.org/10.2307/2950507

Delmas, M. A., Nairn-Birch, N., \& Balzarova, M. (2013). Choosing the right eco-label for your product. MIT Sloan Management Review, 54(4), 10.

Dhar, S. K., \& Hoch, S. J. (1997). Why store brand penetration varies by retailer. Marketing Science, 16(3), 208-227. https://doi.org/10.1287/mksc.16.3.208

D'Souza, C. (2004). Ecolabel programmes: a stakeholder (consumer) perspective. Corporate Communications: An International Journal, 9(3), 179-188. https://doi.org/10.1108/13563280410551105

De Boer, J. (2003). Sustainability labelling schemes: the logic of their claims and their functions for stakeholders. Business Strategy and the Environment, 12(4), 254-264. https://doi.org/10.1111/1467-9361.0018810.1002/bse.362

Du Preez, J. P., Diamantopoulos, A., \& Schlegelmilch, B. B. (1994). Product standardization and attribute saliency: A three-country empirical comparison. Journal of International Marketing, 7-28.

Eco-Labelling, O. E. C. D. (1997). Actual Effects of Selected Programmes. Paris: Organization for Economic Cooperation and Development.

Erskine, C. C., \& Collins, L. (1997). Eco-labelling: success or failure?. The Environmentalist, 17(2), 125-133. https://doi.org/10.1023/A:1018552000651

Ezrachi, A., \& Bernitz, U. (2009). Private Labels, Brands and Competition Policy: The Changing Landscape of Retail Competition. Oxford University Press.

Eurobarometer, F. (2009). Europeans' attitudes towards the issue of sustainable consumption and production. Flash Eurobarometer, 256.

Fitzgerald, K. (1993). It's green, it's friendly, it's wal-mart, eco-store. Advertising Age, 1, 44.

Fotopoulos, C., \& Krystallis, A. (2002). Organic product avoidance: reasons for rejection and potential buyers' identification in a countrywide survey. British Food Journal, 104(3/4/5), 233-260. https://doi.org/10.1108/00070700210425697

Fowler Jr, F. J. (2013). Survey research methods. Sage publications.

Galarraga Gallastegui, I. (2002). The use of eco-labels: A review of the literature. Environmental Policy and Governance, 12(6), 316-331. https://doi.org/10.1002/eet.304 
Galizzi, G., Venturini, L., \& Boccaletti, S. (1997). Vertical relationships and dual branding strategies in the Italian food $\quad$ industry. $\quad$ Agribusiness, 132 13), https://doi.org/10.1002/(SICI)1520-6297(199703/04)13:2<185::AID-AGR7>3.0.CO;2-Z

Gendel-Guterman, H., Gendel-Guterman, H., Levy, S., \& Levy, S. (2017). Consumer response to private label brands' negative publicity: a relational effect on retailer's store image. Journal of Product \& Brand Management, 26(2), 204-222. https://doi.org/10.1108/JPBM-05-2015-0880

Gielens, K. (2018). The Competitive Price Effects of Lidl's Entry in the US Grocery Market.

Girard, T., Trapp, P., Pinar, M., Gulsoy, T., \& Boyt, T. E. (2017). Consumer-Based Brand Equity of a Private-Label Brand: Measuring and Examining Determinants. Journal of Marketing Theory and Practice, 25(1), 39-56. https://doi.org/10.1080/10696679.2016.1236662

Gyongyi, J. K., Aniko, J., \& Marta, S. (2012). Impacts of the Production of Private Labels on the Food Retailing and Its Suppliers. Economics and Rural Development, 8(2), 31-36.

Hansen, T., Sørensen, M. I., \& Eriksen, M. L. R. (2018). How the interplay between consumer motivations and values influences organic food identity and behavior. Food Policy, 74, 39-52. https://doi.org/10.1016/j.foodpol.2017.11.003

Hartlieb, S., \& Jones, B. (2009). Humanising business through ethical labelling: Progress and paradoxes in the UK. Journal of Business Ethics, 88(3), 583-600. https://doi.org/10.1007/s10551-009-0125-x

Hill, H., \& Lynchehaun, F. (2002). Organic milk: attitudes and consumption patterns. British Food Journal, 104(7), 526-542. https://doi.org/10.1108/00070700210434570

Hinloopen, J., \& Martin, S. (1997). Market Structure Determinants of National Brand-Private Label Price Differences of Manufactured Food Products. Comment: The Journal of Industrial Economics, 45, 219-223. https://doi.org/10.1111/1467-6451.00045

Horne, R. E. (2009). Limits to labels: The role of eco-labels in the assessment of product sustainability and routes to sustainable consumption. International Journal of Consumer Studies, 33(2), 175-182. https://doi.org/10.1111/j.1470-6431.2009.00752.x

Huang, C. L. (1996). Consumer preferences and attitudes towards organically grown produce. European Review of Agricultural Economics, 23(3), 331-342. https://doi.org/10.1093/erae/23.3.331

Hughner, R. S., McDonagh, P., Prothero, A., Shultz, C. J., \& Stanton, J. (2007). Who are organic food consumers? A compilation and review of why people purchase organic food. Journal of Consumer Behaviour, 6(2-3), 94-110. http://dx.doi.org/10.1002/cb.210

Hutchins, R. K., \& Greenhalgh, L. A. (1995). Organic confusion: sustaining competitive advantage. Nutrition \& Food Science, 95(6), 11-14. https://doi.org/10.1108/00346659510103584

Iraldo, F., Lanzini, P., Melis, M., Kahlenborn, W., Freier, I., Rubik, F., Ankele, K., Scheer, D. and Hertin, J. (2005). EVER: Evaluation of Emas and Eco-Label for Their Revision. Report 2: Research Findings, IEFE Universita` Bocconi, Adelphi Consult, IOEW, SPRU Sussex University, and Valor \& Tinge A/S, Milan.

Jolly, D. A. (1990). Determinants of organic horticultural products consumption based on a sample of California consumers. Horticultural Economics and Marketing, 295, 141-148. https://doi.org/10.17660/ActaHortic.1991.295.18

Jonas, A., \& Roosen, J. (2005). Private labels for premium products-the example of organic food. International Journal of Retail \& Distribution Management, 33(8), 636-653. https://doi.org/10.1108/09590550510608412

Kassarjian, H. H. (1971). Incorporating ecology into marketing strategy: The case of air pollution. The Journal of Marketing, 61-65. https://doi.org/10.2307/1249791

Kelting, K., Duhachek, A., \& Whitler, K. (2017). Can copycat private labels improve the consumer's shopping experience? A fluency explanation. Journal of the Academy of Marketing Science, 1-17. https://doi.org/10.1007/s11747-017-0520-2

Kotler, P., \& Armstrong, G. (1996). Principles of Marketing, seventh ed. Prentice-Hall International, Inc., NJ

Lienbacher, E., Holweg, C., Rychly, N., \& Schnedlitz, P. (2013). CSR in food retailing: what's really on customers'minds?. In Proceedings of the AMA WinterMarketing Educator's Conference. USA, American Marketing Association (pp. 235-243).

Liu, R. L., Sprott, D. E., Spangenberg, E. R., Czellar, S., \& Voss, K. E. (2018). Consumer preference for national 
vs. private brands: The influence of brand engagement and self-concept threat. Journal of Retailing and Consumer Services, 41, 90-100. https://doi.org/10.1016/j.jretconser.2017.11.010

Magnusson, M. K., Arvola, A., Koivisto Hursti, U. K., Åberg, L., \& Sjödén, P. O. (2001). Attitudes towards organic foods among Swedish consumers. British Food Journal, 103(3), 209-227. https://doi.org/10.1108/00070700110386755

Mathews, R. (1996). The new age of retailer controlled brands. Progressive Grocer, A2-A19.

Mills, D. E. (1995). Why retailers sell private labels. Journal of Economics \& Management Strategy, 4(3), 509-528. https://doi.org/10.1111/j.1430-9134.1995.00509.x

Morrone, D. (2012). The influence of sustainable development on marketing theory. Megatrend Review, 9(4).

Narasimhan, C., \& Wilcox, R. T. (1998). Private labels and the channel relationship: a cross-category analysis. The journal of business, 71(4), 573-600. https://doi.org/10.1086/209757

Nenycz-Thiel, M., \& Romaniuk, J. (2016). Understanding premium private labels: A consumer categorisation approach. Journal of Retailing and Consumer Services, 29, 22-30. https://doi.org/10.1016/j.jretconser.2015.10.008

Olbrich, R., Jansen, H. C., \& Hundt, M. (2017). Effects of pricing strategies and product quality on private label and national brand performance. Journal of Retailing and Consumer Services, 34, 294-301. https://doi.org/10.1016/j.jretconser.2016.01.012

Osservatorio Marca (2018). XIV Rapporto Marca

Ott, S., L. (1990). Supermarkets shoppers' pesticide concerns and willingness to purchase certified pesticide $\begin{array}{lllll}\text { residue-free } & \text { fresh } & \text { produce. }\end{array}$ https://doi.org/10.1002/1520-6297(199011)6:6<593::AID-AGR2720060606>3.0.CO;2-Z

Ottman, J. A. (1993). Green marketing: challenges and opportunities for the new marketing age (p. 10). Lincolnwood, IL: NTC Business Books.

Paul, J., \& Rana, J. (2012). Consumer behavior and purchase intention for organic food. Journal of consumer Marketing, 29(6), 412-422. https://doi.org/10.1108/07363761211259223

Peštek, A., Agić, E., \& Činjarević, M. (2018). Segmentation or organic food buyers: an emergent market perspective. British Food Journal. https://doi.org/10.1108/BFJ-04-2017-0215

Piacentini, M., MacFadyen, L., \& Eadie, D. (2000). Corporate social responsibility in food retailing. International Journal of Retail \& Distribution Management, 28(11), 459-469. https://doi.org/10.1108/09590550010356822

Popović, A., Golijan, J., Sečanski, M., \& Čamdžija, Z. (2018). Current Status and Future Prospects of Organic Cereal Production in the World. АГРОЗНАЬЕ, 18(3), 199-207.

Porter, M. E., \& Van der Linde, C. (1995). Toward a new conception of the environment-competitiveness relationship. The journal of economic perspectives, 9(4), 97-118.

Putsis, W. P. (1997). An empirical study of the effect of brand proliferation on private label-national brand pricing behavior. Review of industrial Organization, 12(3), 355-371. https://doi.org/10.1023/A:1007704421589

Reinders, M. J., \& Bartels, J. (2017). The roles of identity and brand equity in organic consumption behavior: Private label brands versus national brands. Journal of Brand Management, 24(1), 68-85. https://doi.org/10.1057/s41262-016-0019-z

Roddy, G., Cowan, C., Hutchinson, G., (1994). Organic food: a description of the Irish market. British Food Journal, 96(4), 3-10. https://doi.org/10.1108/00070709410060998

Roheim, C. A. (2009). Ecolabelling of fisheries products: assessment of its benefits. International seafood trade: challenges and opportunities, 85 .

Rossi, P., Borges, A., \& Bakpayev, M. (2015). Private labels versus national brands: The effects of branding on sensory perceptions and purchase intentions. Journal of Retailing and Consumer Services, 27, 74-79. https://doi.org/10.1016/j.jretconser.2015.07.006

Scerbinski, J. S. (1991). Consumers and the Environment: A focus on five products. Journal of Business Strategy, 12(5), 44-47. https://doi.org/10.1108/eb039443 
Schmeltz, L. (2012). Consumer-oriented CSR communication: focusing on ability or morality? Corporate Communications: An International Journal, 17(1), 29-49. https://doi.org/10.1108/13563281211196344

Schifferstein, H. N., \& Ophuis, P. A. O. (1998). Health-related determinants of organic food consumption in the Netherlands. Food quality and Preference, 9(3), 119-133. https://doi.org/10.1016/S0950-3293(97)00044-X

Sitarz, D. (1994). Agenda 21: The Earth Summit Strategy to Save Our Planet. EarthPress, Boulder, CO.

Soler, F., Gil, J. M., \& Sanchez, M. (2002). Consumers' acceptability of organic food in Spain: results from an experimental auction market. British Food Journal, 104(8), 670-687. https://doi.org/10.1108/00070700210425921

Squires, L., Juric, B., \& Bettina Cornwell, T. (2001). Level of market development and intensity of organic food consumption: cross-cultural study of Danish and New Zealand consumers. Journal of Consumer Marketing, 18(5), 392-409. https://doi.org/10.1108/07363760110398754

Sultan, P., Wong, H. Y., \& Sigala, M. (2018). Segmenting the Australian organic food consumer market. Asia Pacific Journal of Marketing and Logistics, 30(1), 163-181. https://doi.org/10.1108/APJML-10-2016-0211

Tang, E., Fryxell, G. E., \& Chow, C. S. (2004). Visual and verbal communication in the design of eco-label for green consumer products. Journal of International Consumer Marketing, 16(4), 85-105. https://doi.org/10.1300/J046v16n04_05

Thøgersen, J. (2002). Promoting green consumer behavior with eco-labels, in Dietz, T. and Stern, P. (Eds), New Tools for Environmental Protection: Education, Information, and Voluntary Measures, National Academy Press, Washington, DC, pp. 83-104.

Thøgersen, J., Pedersen, S., Paternoga, M., Schwendel, E., \& Aschemann-Witzel, J. (2017). How important is country-of-origin for organic food consumers? A review of the literature and suggestions for future research. British Food Journal, 119(3), 542-557. https://doi.org/10.1108/BFJ-09-2016-0406

Thompson, G., D., Kidwell, J. (1998). May. Explaining the choice of organic produce: cosmetic defects prices, and consumer preferences. American Journal of Agricultural Economics, 80(2), 277-287. https://doi.org/10.2307/1244500

Tregear, A., Dent, J. B., \& McGregor, M. J. (1994). The demand for organically grown produce. British Food Journal, 96(4), 21-25. https://doi.org/10.1108/00070709410061032

Ward, M. B., Shimshack, J. P., Perloff, J. M., \& Harris, J. M. (2002). Effects of the private-label invasion in food industries. American Journal of Agricultural Economics, 84(4), 961-973. https://doi.org/10.1111/1467-8276.00360

Wandel, M., \& Bugge, A. (1997). Environmental concern in consumer evaluation of food quality. Food quality and preference, 8(1), 19-26. https://doi.org/10.1016/S0950-3293(96)00004-3

Wu, P. C., Yeh, G. Y. Y., \& Hsiao, C. R. (2011). The effect of store image and service quality on brand image and purchase intention for private label brands. Australasian Marketing Journal (AMJ), 19(1), 30-39. https://doi.org/10.1016/j.ausmj.2010.11.001

Zanoli, R., \& Naspetti, S. (2002). Consumer motivations in the purchase of organic food: A means-end approach. British food journal, 104(8), 643-653. https://doi.org/10.1108/00070700210425930

Zucconi, S. (2017). Nuovi trend del biologico in Italia: il ruolo dei prodotti bio per vegetariani e vegani, carried out by Nomisma, curated by International Exhibition of Organic and Natural Products (Sana) and promoted by Italy Trade Agency.

\section{Notes}

Note 1. Council Regulation (EC) No. 834/2007

Note 2. Source: https://ec.europa.eu/agriculture/organic/eu-policy/eu-legislation/brief-overview_en (last access November 21, 2017)

Note 3. Commission Regulation (EU) No 271/2010 of 24 March 2010

Note 4. "Nomisma is an independent company that carries out economic research and consulting for businesses, associations and public administrations at national and international levels". Source: http://www.nomisma.it/index.php/en/about-us. 
Note 5. "Censis was founded as a social study and research institute in 1964, becoming a legally recognised Note 6. Source: XIV ${ }^{\circ}$ Rapporto Marca (2018) - Osservatorio Marca.

\section{Copyrights}

Copyright for this article is retained by the author(s), with first publication rights granted to the journal.

This is an open-access article distributed under the terms and conditions of the Creative Commons Attribution license (http://creativecommons.org/licenses/by/4.0/). 